\title{
Identification of oxidized protein hydrolase as a potential prodrug target in prostate cancer
}

\author{
Christopher A McGoldrick', Yu-Lin Jiang ${ }^{2}$, Victor Paromov ${ }^{1}$, Marianne Brannon', Koyamangalath Krishnan ${ }^{3}$ \\ and William L Stone ${ }^{1 *}$
}

\begin{abstract}
Background: Esterases are often overexpressed in cancer cells and can have chiral specificities different from that of the corresponding normal tissues. For this reason, ester prodrugs could be a promising approach in chemotherapy. In this study, we focused on the identification and characterization of differentially expressed esterases between non-tumorigenic and tumorigenic prostate epithelial cells.

Methods: Cellular lysates from LNCaP, DU 145, and PC3 prostate cancer cell lines, tumorigenic RWPE-2 prostate epithelial cells, and non-tumorigenic RWPE-1 prostate epithelial cells were separated by native polyacrylamide gel electrophoresis (n-PAGE) and the esterase activity bands visualized using a-naphthyl acetate or a-naphthyl-N-acetylalaninate (ANAA) chiral esters and Fast Blue RR salt. The esterases were identified using nanospray LC/MS-MS tandem mass spectrometry and confirmed by Western blotting, native electroblotting, inhibition assays, and activity towards a known specific substrate. The serine protease/esterase oxidized protein hydrolase $(\mathrm{OPH})$ was overexpressed in COS-7 cells to verify our results.

Results: The major esterase observed with the ANAA substrates within the n-PAGE activity bands was identified as OPH. $\mathrm{OPH}$ (EC 3.4.19.1) is a serine protease/esterase and a member of the prolyl oligopeptidase family. We found that LNCaP lysates contained approximately 40\% more OPH compared to RWPE-1 lysates. RWPE-2, DU145 and PC3 cell lysates had similar levels of OPH activity. OPH within all of the cell lysates tested had a chiral preference for the S-isomer of ANAA. LNCaP cells were stained more intensely with ANAA substrates than RWPE-1 cells and COS-7 cells overexpressing OPH were found to have a higher activity towards the ANAA and AcApNA than parent COS-7 cells.
\end{abstract}

Conclusions: These data suggest that prodrug derivatives of ANAA and AcApNA could have potential as chemotherapeutic agents for the treatment of prostate cancer tumors that overexpress $\mathrm{OPH}$.

\section{Background}

Prostate cancer is the second most frequently diagnosed cancer in men and the second-leading cause of cancer related death in American men [1]. There is an estimated 238,590 new cases of prostate cancer predicted in the US this year and an estimated 29,720 deaths due to prostate cancer [1]. Despite advances in radiation and chemotherapy, prostate cancer is a leading cause of cancer death. Radiation and chemotherapy treatment remain central to prostate cancer treatment. These treatments can, however, produce a number of side effects such as neutropenia $[2,3]$, urinary and bowel symptoms [4], hair loss [5], and

\footnotetext{
* Correspondence: stone@etsu.edu

'Department of Pediatrics, East Tennessee State University, P.O. Box 70579, Johnson City, TN 37614, USA

Full list of author information is available at the end of the article
}

fatigue [6]. There is, therefore, a critical need to develop tumor specific therapies for prostate cancer.

Selective activation of anti-cancer drugs within cancer cells is a promising strategy to minimize the toxic effects of anticancer drugs on normal tissues [7-10]. As indicated in Figure 1, the esterase prodrug strategy utilizes pharmacological compounds that are blocked by esterification but are activated when cancer cell esterases cleave the ester bond and release the active drug [11]. A degree of specificity can be achieved if the cancer cell esterase is overexpressed compared to normal tissue. In order to optimize potential chemotherapeutic prodrug esters it is important to characterize and identify any differentially expressed esterases.

Yamazaki et al. [12-14] examined the esterase activity profiles of various human and animal cancer tumors using n-PAGE and esterase activity staining. These researchers 


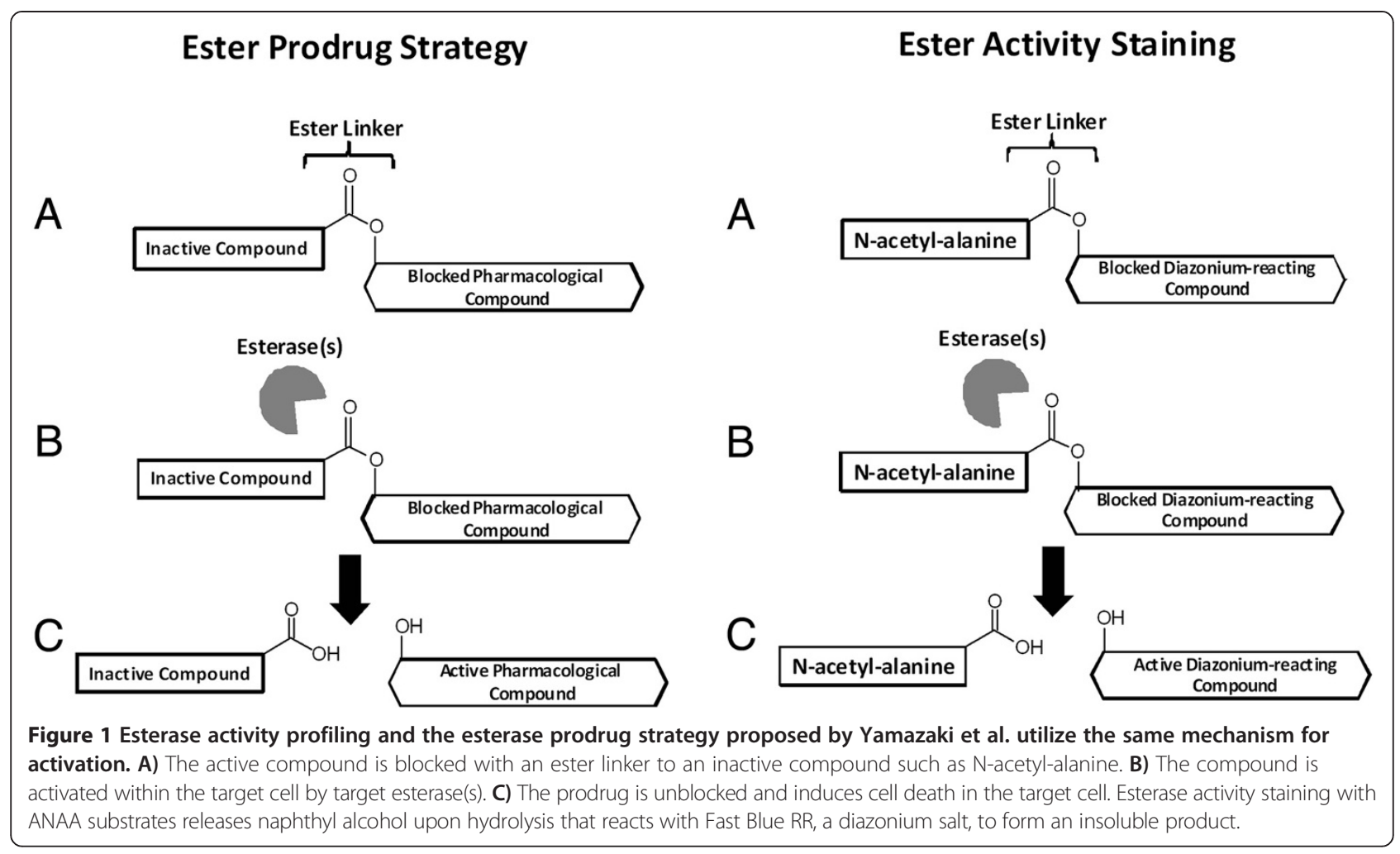

found that lysates from cancer tumors often had a different level of activity and a different stereoselectivity towards several chiral esters than the corresponding normal tissues. Moreover, Yamazaki et al. suggested these differences in esterase activities could be exploited to develop prodrugs that selectively target cancer cells $[13,14]$. The esterases observed by Yamazaki et al. [12-14] were, however, never identified. The primary focus of the work presented here was to identify the specific esterases differentially expressed in tumorigenic human prostate cancer cells and in nontumorigenic prostate epithelial cells. We compared the esterase activity profiles of RWPE-2, LNCaP, DU 145, and PC-3 tumorigenic prostate cell lines to RWPE-1 nontumorigenic prostate epithelial cells using the $\alpha$-naphthyl acetate substrate and the chiral naphthyl ester substrates $\alpha$-naphthyl $\mathrm{N}$-acetyl-S-alaninate (S-ANAA) and $\alpha$-naphthyl $\mathrm{N}$-acetyl-R-alaninate (R-ANAA). These substrates were previously used by Yamazaki et al. [13]. Figure 2 shows the structures of the various substrates. In addition, we have advanced the Yamazaki method of detecting esterases by using a native electroblot method that markedly increases the sensitivity for detecting esterase activity bands compared to that observed in n-PAGE gels.

We identified oxidized protein hydrolase $(\mathrm{OPH})$, also called N-acylaminoacyl-peptide hydrolase (APEH), as a key esterase that is overexpressed in the tumorigenic LNCaP cell line. $\mathrm{OPH}$ is a serine esterase/protease that has a well characterized esterase activity towards $\alpha$-naphthyl butyrate
[15] and an exopeptidase activity for removing the $\mathrm{N}$-terminally acetylated amino acid residues from peptides/ proteins [15-17]. Immunohistochemistry of primary prostate tumor sections indicate that $\mathrm{OPH}$ is highly expressed in some prostate tumors (http://www.proteinatlas.org/), suggesting that $\mathrm{OPH}$ could have potential as a drug target in prostate cancer. The overexpression of $\mathrm{OPH}$ in some prostate cancers suggests that chemotherapeutic prodrugs esters modeled after known ester substrates of $\mathrm{OPH}$ (i.e., $\alpha$-naphthyl $\mathrm{N}$-acetyl-alaninate) have potential in treating some prostate cancers.

\section{Methods}

\section{Materials}

Porcine liver esterase (PLE), digitonin, $\alpha$-naphthyl acetate, fast blue RR salt, goat anti-rabbit HRP conjugate polyclonal antibody, and diisopropyl fluorophosphate (DFP) were purchased from Sigma Chemical Company (St. Louis, MO). Novex Tris-glycine native sample buffer, NuPAGE LDS sample buffer, Novex Tris-glycine gels, NativeMark unstained protein standards, Protein A agarose beads, penicillin/streptomycin solution, and geneticin (G418) were purchased from Invitrogen (Grand Island, NY). Precision plus protein standards were purchased from Bio-Rad (Hercules,CA); the BCA kit and the In-gel tryptic digestion kit were purchased from Pierce (Rockford, IL); ZipTipU-C18 tips were purchased from Millipore (Billerica, MA); 3,3',5,5'-tetramethylbenzidine (TMB) was purchased 
<smiles>CC(=O)Oc1cccc2ccccc12</smiles>

$\alpha$-naphthyl acetate<smiles>CC(=O)N[C@@H](C)C(=O)Oc1cccc2ccccc12</smiles>

a-naphthyl (R)-N-acetylalaninate (R-ANAA)<smiles>CC(=O)N[C@@H](C)C(=O)Oc1cccc2ccccc12</smiles>

$\alpha$-naphthyl (S)-N-acetylalaninate (S-ANAA)<smiles>CC(=O)N[C@@H](C)C(=O)Nc1ccc([N+](=O)[O-])cc1</smiles>

$\mathrm{N}$-acetyl-alanyl-p-nitroanilide (AcApNA)

Figure 2 Structures of compounds used to evaluate esterase activity profiles. A) a-naphthyl acetate is a non-specific esterase substrate and is used to visualize general esterase activity. B) S-ANAA and C) R-ANAA are chiral esters previously used by Yamazaki et al. to demonstrate stereoselective preferences between cancer and normal cells. D) N-acetyl-L-alanyl-p-nitroanilide releases $p$-nitroanaline upon hydrolysis and is routinely used to monitor $\mathrm{OPH}$ activity.

from Promega (Madison, WI); rabbit polyclonal anti-AARE antibody was purchased from Abcam (Cambridge, MA); superose 12 column (10/300 GL) was purchased from GE Healthcare (Pittsburgh, PA); (TransIT-LT1 transfection reagent was purchased from Mirus Bio (Madison, WI). pCDNA3.1(+) vector encoding OPH-Flag was a kind gift from Dr. M. Hayakawa (Tokyo University of Pharmacy and Life Sciences, Tokyo, Japan).

\section{Substrates}

R- and S- isomers of ANAA (Figure 2) were synthesized and purified as previously described [13] and stored at $-20^{\circ} \mathrm{C}$. Stock solutions of $100 \mathrm{mM} \alpha$-naphthyl acetate were prepared in DMSO and stored at $-20^{\circ} \mathrm{C}$. The synthesis of N-acetyl-alanyl-p-nitroanilide (AcApNA) was guided by a previously published procedure [18]. AcApNA was synthesized by adding $20 \mathrm{ml}$ of dichloromethane to a solution of anhydrous dimethylformamide $(0.51 \mathrm{ml})$ and $0.865 \mathrm{~g}$ of $\mathrm{N}$-acetyl-L-alanine. The mixture was cooled to $-20^{\circ} \mathrm{C}$ with an acetone-dry ice bath. Thionyl chloride $(0.485 \mathrm{ml})$ was added dropwise to the cooled mixture. After $20 \mathrm{~min}$, a cold solution $\left(-20^{\circ} \mathrm{C}\right)$ of $0.828 \mathrm{~g}$ 4-nitroanaline and $1.82 \mathrm{ml}$ of triethylamine in $10 \mathrm{ml}$ of dichloromethane was added dropwise to the $\mathrm{N}$-acetyl-L-alanine solution. The resulting mixture was maintained at $0^{\circ} \mathrm{C}$ for $2 \mathrm{~h}$. After concentration, the mixture was extracted with ethyl acetate $(2 \times 30 \mathrm{ml})$. The organic layer was washed with $4 \mathrm{~N} \mathrm{HCl}(2 \times 40 \mathrm{ml})$ and $\mathrm{NH}_{4} \mathrm{Cl}$ aqueous solution $(40 \mathrm{ml})$, and dried over $\mathrm{MgSO}_{4}$. After filtration and concentration of the organic layer, the residue was purified using column chromatography with hexane, then 30-50\% acetone in hexane, affording $0.248 \mathrm{~g}$ of the final product (16\%). M.P. was found to be $194-196^{\circ} \mathrm{C}$. The M.P. has been previously reported as $192-197^{\circ} \mathrm{C}$ [19]).

\section{Cell culture and lysates}

RWPE-1 (CRL-11609), RWPE-2 (CRL-11610), LNCaP (CRL-1704), DU-145 (HTB-81), PC-3 (CRL-1435) and COS-7 (CRL-1651) cell lines were purchased from American Type Culture Collection (Manassas, VA), cultured according to ATCC's instructions and supplemented with $100 \mathrm{U} / \mathrm{ml}$ penicillin and $100 \mathrm{mg} / \mathrm{ml}$ streptomycin. Cells were detached from the $75 \mathrm{~cm}^{3}$ cell culture flasks after reaching $80 \%$ confluence by washing the cells with PBS followed by the addition of $0.25 \%$ trypsin. The detached cells were centrifuged at $500 \times \mathrm{g}$ for 5 mins and washed with PBS to remove trypsin. Cells were centrifuged a second time and pellets stored at $-80^{\circ} \mathrm{C}$. Cell pellets of each cell line were lysed using $2 \%$ (wt/vol) digitonin in PBS on ice with vortexing every two minutes. After $10 \mathrm{~min}$ of incubation on ice, the lysates were centrifuged at 18,000 $\times \mathrm{g}$ for $5 \mathrm{~min}$ at $4^{\circ} \mathrm{C}$ and the supernatant collected. Protein concentrations were determined with the BCA kit using the manufacturer's instructions.

\section{n-PAGE esterase activity profiles}

Cell lysates containing $120 \mu \mathrm{g}$ of protein were mixed with an equal volume of $2 \mathrm{X}$ Novex Tris-glycine native sample buffer and applied to a Novex $10-20 \%$ or $6 \%$ Tris-glycine gel. NativeMark unstained protein standards were used as migration markers. Gels were electrophoresed under native 
conditions at $4^{\circ} \mathrm{C}$ using $20 \mathrm{~mA} /$ gel for $270 \mathrm{~min}$ for the $10-20 \%$ gel or $180 \mathrm{~min}$ for the $6 \%$ gels. For inhibition assays, the gel lanes were separated and immersed in either $0.1 \mathrm{M}$ sodium phosphate buffer, $\mathrm{pH} 6.5$ or sodium phosphate buffer containing $50 \mu \mathrm{M}$ DFP for $10 \mathrm{~min}$. The gels were then stained for esterase activity by immersing them in $30 \mathrm{ml}$ of $0.1 \mathrm{M}$ sodium phosphate buffer, $\mathrm{pH} 6.5$ containing $10 \mathrm{mg}$ Fast Blue RR Salt and $800 \mu \mathrm{M} \alpha$-naphthyl acetate or $800 \mu \mathrm{M}$ ANAA isomer. Bands were developed at room temperature for $30 \mathrm{~min}$ followed by 3 washes with distilled water. The migration markers were stained with Coomassie blue and destained overnight in 10\% acetic acid. Gels were scanned with an Epson Perfection V750 PRO scanner.

\section{Semi-purified OPH from rat liver}

$\mathrm{OPH}$ was semi-purified from $100 \mathrm{~g}$ of rat liver using the method described by Tsunasawa [20] with the following modifications. After elution from the hydroxyapatite column, the $\mathrm{OPH}$ fractions were combined and subjected to gel filtration on a Superose12 column (10/300 GL) using a Biologic Duo Flow protein purification system (Bio-Rad, Hercules,CA). Fractions were eluted with $50 \mathrm{mM}$ sodium phosphate buffer, $\mathrm{pH} 7$ containing $1 \mathrm{mM}$ EDTA and $0.2 \mathrm{M}$ $\mathrm{NaCl}$ at a rate of $0.5 \mathrm{ml} / \mathrm{min}$ in $0.5 \mathrm{ml}$ fractions. Fractions that contained $\mathrm{OPH}$ activity were combined and stored at $-20^{\circ} \mathrm{C}$. The pooled semi-purified $\mathrm{OPH}$ was analyzed by mass spectroscopy to verify that no other esterases or proteases were present.

\section{Overexpression of $\mathrm{OPH}$ in COS-7 cells}

COS-7 cells were transfected using TransIT-LT1 transfection reagent and the vector pCDNA3.1(+) encoding $\mathrm{OPH}$ with a Flag tag using the transfection reagent's manufacturer's instructions. COS-7 cells overexpressing $\mathrm{OPH}$ were selected using $1 \mathrm{mg} / \mathrm{ml} \mathrm{G418}$ over a three week period. Cells surviving selection were termed COS-7-OPH for further experiments and were maintained with $1 \mathrm{mg} / \mathrm{ml} \mathrm{G} 418$.

\section{LC/MS-MS mass spectroscopy}

Protein bands were individually excised from the n-PAGE gel and cut into small pieces using a scalpel. The gel pieces were destained, disulfide bonds reduced, unmodified thiol groups alkylated, and the proteins digested with trypsin overnight using the In-Gel Tryptic Digestion Kit (Pierce, Rockford, IL) according to the manufacturer's instructions. After digestion, the liquid containing the peptides from each band was transferred to a $1.5 \mathrm{ml}$ tube. The peptides were further extracted from each gel piece by covering gel piece with extraction buffer consisting of formic acid/acetonitrile/water (5:50:45, v/v/v) for $10 \mathrm{~min}$ then collecting the liquid and adding it to the appropriate $1.5 \mathrm{ml}$ tube. The peptides in the vial inserts were completely dried using a DNA Speed Vac Concentrator (Thermo Fisher Scientific, Asheville, N.C.). Peptides were rehydrated with $0.1 \%$ formic acid and further purified using ZipTipU-C18 tips according to manufacturer's instructions. Peptides eluted from zip tips were transferred to vial inserts. The peptides in the vial inserts were completely dried using the Speed Vac Concentrator and then rehydrated in a volume of $4 \mu \mathrm{l}$ of formic acid/acetonitrile/ water $(0.1: 20: 79.9, \mathrm{v} / \mathrm{v} / \mathrm{v})$. A volume of $2 \mu \mathrm{l}$ of each sample was trapped by a picofrit column packed with $\mathrm{C} 18$ (New Objective, Inc., Woburn, MA) and equilibrated in $0.1 \%$ formic acid in water/acetonitrile (98:2, v/v). Peptides were then eluted with a gradient of 2 to $40 \%$ of solvent B containing $0.1 \%$ formic acid in acetonitrile over $60 \mathrm{~min}$ at a flow rate of $200 \mathrm{~nL} / \mathrm{min}$. Eluted peptides were analyzed by electrospray ionization using a LTQ-XL ion trap mass spectrometer (Thermo Fisher). Mass spectrometry (MS) data were acquired using data-dependent acquisition with a series of one full scan followed by a zoom scan and then a MS/MS scan of the ions. The dynamic exclusion duration was 30 ms. Proteins were identified from each MS raw data file using the SEQUEST search algorithm (Thermo Fisher Scientific) and the SwissProt/UNIPROT database through the Bioworks browser, version 3.3.

\section{SDS-electrophoresis/Western blotting}

Cell lysates containing $90 \mu \mathrm{g}$ of protein were mixed with NuPAGE LDS Sample Buffer, heated to $90^{\circ} \mathrm{C}$, and applied to a Novex 10-20\% Tris-Glycine gel. Precision Plus Protein Standards were used for molecular weight markers. Gels were electrophoresed for $90 \mathrm{~min}$ at $125 \mathrm{~V}$ in $1 \mathrm{X}$ Novex Tris-Glycine SDS running buffer. Gels were then electrophoretically transferred to a nitrocellulose membrane for $90 \mathrm{~min}$ at $25 \mathrm{~V}$. The membrane was probed with 1:1000 rabbit polyclonal anti-AARE $(\mathrm{OPH})$ antibody (ab84694, Abcam) or anti-GAPDH (ab9485, Abcam) overnight at $4{ }^{\circ} \mathrm{C}, 1: 2000$ anti-rabbit IgG conjugated to HRP (A0545-1ML, Sigma) was used as the secondary antibody and incubated for 1 hour. Membranes were washed with PBS containing $0.05 \%$ Tween 20. Peroxidase was detected using $3,3^{\prime}, 5,5^{\prime}$-tetramethylbenzidine according to manufacturer's instructions.

\section{Native electroblot activity staining and western blotting}

Native electroblot activity staining was carried out by electrophoretically transferring proteins from n-PAGE gels to a nitrocellulose membrane at $4^{\circ} \mathrm{C}$, followed by the esterase activity staining procedure (see above). Western blots of the n-PAGE gel were carried out by probing a native electroblot as described in the Western blotting methods.

\section{OPH-cleared lysate}

An aliquot of $0.5 \mathrm{ml}$ Protein A agarose beads was coupled with $5 \mu \mathrm{g}$ of anti-OPH antibody on ice for $30 \mathrm{~min}$. LNCaP cell lysates containing $120 \mu \mathrm{g}$ of protein was combined with either Protein A agarose beads or anti-OPH conjugated 
Protein A agarose beads and incubated on ice for 1 hour with gentle mixing every $15 \mathrm{~min}$. The samples were centrifuged for $5 \mathrm{~min}$ at $1000 \times \mathrm{g}$ and the supernatants were then separated using 6\% n-PAGE followed by the esterase activity staining procedure.

\section{OPH activity assay}

Aliquots of $20 \mu \mathrm{L}$ of cell lysates containing either $4.5 \mu \mathrm{g} / \mu \mathrm{l}$ of protein, or 0.5 unit PLE, or $12.5 \mathrm{ng} / \mu \mathrm{l}$ semi-purified rat liver OPH, or PBS were added in triplicate to a 96 well microplate. One unit of PLE is defined as the amount of PLE that will hydrolyze $1.0 \mu$ mole of ethyl butyrate to butyric acid and ethanol per min at $\mathrm{pH} 8.0$ at $25^{\circ} \mathrm{C}$. An assay cocktail of $220 \mu \mathrm{L} 0.1 \mathrm{M}$ sodium phosphate buffer, pH 6.5 and $10 \mu \mathrm{l}$ of $100 \mathrm{mM}$ AcApNA was added to each well giving a final AcApNA concentration of $4 \mathrm{mM}$. The release of $\mathrm{p}$-nitroaniline was monitored with a microplate reader at a wavelength of $405 \mathrm{~nm}$ for $10 \mathrm{~min}$ at room temperature. The concentration of p-nitroaniline was calculated using a molecular extinction coefficient of $7530 \mathrm{M}^{-1} \mathrm{~cm}^{-1}$.

\section{Cell culture esterase staining}

LNCaP, RWPE-1, COS-7, and COS-7-OPH were seeded in triplicate in 24 well cell culture plates at $1 \times 10^{5}$ cells/well. The plate was incubated at $37^{\circ} \mathrm{C}$ in a $\mathrm{CO}^{2}$ incubator overnight. Staining solutions of $0.1 \mathrm{M}$ sodium phosphate buffer, pH 6.5 containing $10 \mathrm{mg}$ Fast Blue RR Salt and $800 \mu \mathrm{M}$ $\alpha$-naphthyl acetate or $800 \mu \mathrm{M} \alpha$-naphthyl $\mathrm{N}$-acetylalaninate isomer were prepared immediately prior to cell staining. The cell media was removed from each well and $500 \mu \mathrm{l}$ of staining solution was added to each well. The cells were incubated at $37^{\circ} \mathrm{C}$ in $5 \% \mathrm{CO}_{2}$ for 20 minutes. The staining solution was removed and replaced with $500 \mu \mathrm{l}$ of PBS. The cells were observed at $100 \mathrm{x}$ magnification and digitally photographed using a MOTIC inverted phase contrast microscope equipped with a Nikon Coolpix E4300 4-megapixel camera (Martin Microscope, Easley, SC). The percent area threshold of staining was measured using ImageJ, v1.44o (NIH, Bethesda, MD).

\section{Statistics}

Data were analyzed by analysis of variance (ANOVA) followed with the Scheffe test for significance with $\mathrm{P}<0.05$ using SPSS 19.0 for Windows (Chicago, Illinois). Results were expressed as the mean $\pm \mathrm{SD}$ of at least three experiments. In all figures, letters that are not the same are significantly different with $\mathrm{P}<0.05$.

\section{Ethics}

The research conducted in this study adhered to US NIH ethical guidelines. All the human cell lines studied were purchased from the American Type Culture Collection and such studies are not considered human subjects research because the cell lines are publicly available and all of the information known about the cell lines is also publicly available. No experimental animals were used in the studies reported here.

\section{Results \\ Differential esterase activity between non-tumorigenic RWPE-1 and tumorigenic LNCaP cells}

Our first objective was to determine if non-tumorigenic prostate cells have a different n-PAGE esterase activity profile compared to tumorigenic prostate cells and to characterize any chiral ester substrate preferences.

Proteins from non-tumorigenic RWPE-1 and tumorigenic LNCaP human prostate cell lysates were separated by n-PAGE on a 10-20\% gradient gel and stained for esterase activity (Figure 3A) using either $\alpha$-naphthyl acetate, R-ANAA, or S-ANAA substrates (Figure 2A-C) and Fast Blue RR salt. General esterase activity, as visualized by $\alpha$-naphthyl acetate activity staining $[21,22]$, was markedly higher in the tumorigenic $\mathrm{LNCaP}$ lysate compared to the non-tumorigenic RWPE-1 lysate. Parallel gels stained with either R-ANAA or S-ANAA substrates revealed fewer esterase bands than with $\alpha$-naphthyl acetate. The chiral substrates revealed two prominent bands that migrated at native protein molecular weight markers locations corresponding to " $432 \mathrm{kDa}$ " and " $359 \mathrm{kDa}$ ". Protein migration in n-PAGE electrophoresis is influenced by size, conformation and charge and, therefore, the "native $\mathrm{kDa}$ markers" in Figure 3A were used only to provide a reproducible measure of electrophoretic migration patterns rather than a meaningful measure of true molecular weight. As shown in Figure 3A, both the " $432 \mathrm{kDa}$ " and the " $359 \mathrm{kDa}$ " bands were markedly more stained in the LNCaP cell lysates compared to the RWPE-1 cell lysates and both bands showed higher staining with S-ANAA compared to the R-ANAA chiral substrate. Densitometry analysis of the $432 \mathrm{kDa}$ and $359 \mathrm{kDa}$ esterase bands (Figure 3B-C) showed approximately a $30 \%$ increase in activity with S-ANAA compared to R-ANAA and approximately $40 \%$ more activity with LNCaP lysates compared to RWPE-1 lysates.

\section{Prostate esterases identified as $\mathrm{OPH}$ have a preference for S-ANAA}

Initial attempts to identify the esterases within the "432 kDa" and "359 kDa" bands by LC/MS-MS were hindered by the large number of non-esterase proteins. To further characterize esterase activity in human prostate cells, we next examined cell lysates of several human prostate cell lines for esterase activity using 6\% n-PAGE followed by activity staining with $\alpha$-naphthyl acetate, or chiral ester substrates R-ANAA, or S-ANAA (Figure 4A). By performing 6\% n-PAGE electrophoresis, the higher MW proteins were better separated and esterase bands generally more defined. The n-PAGE esterase activity profiles 


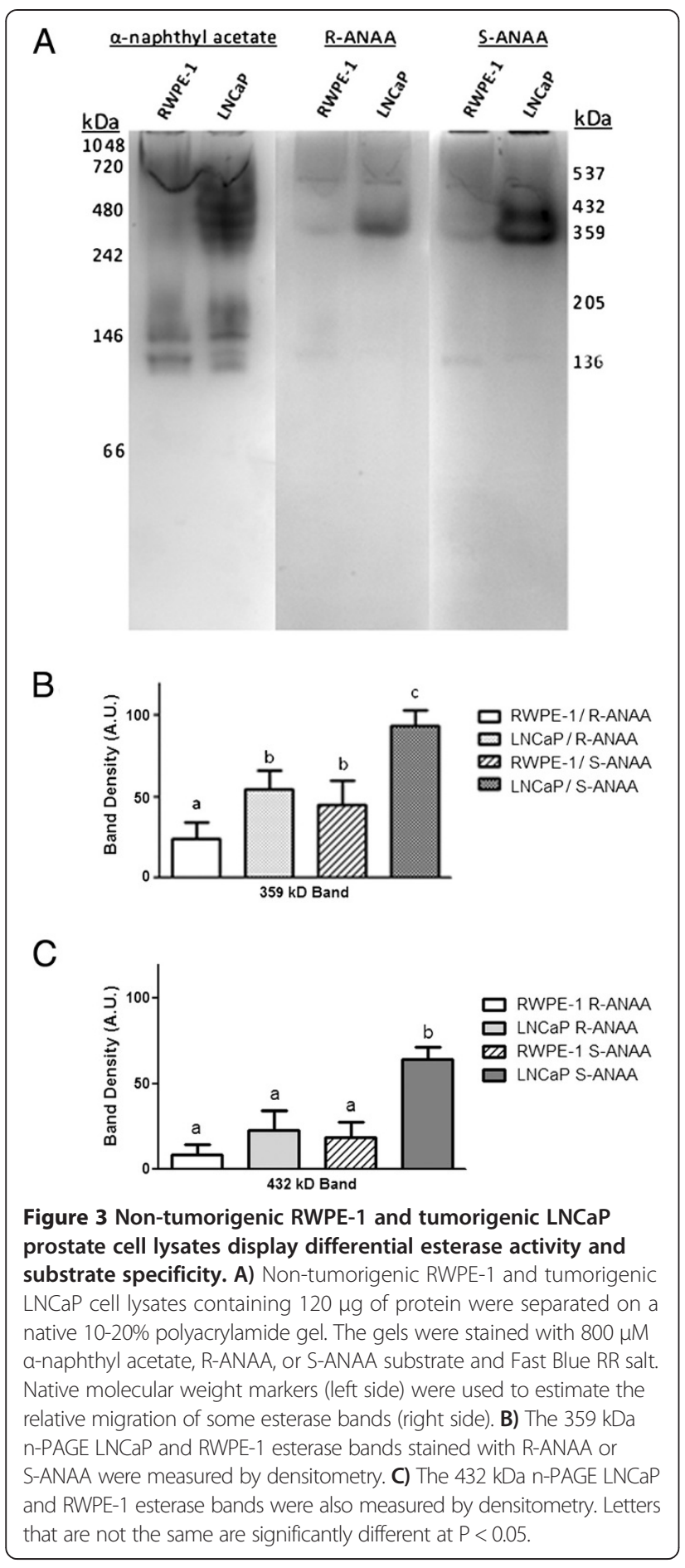

obtained with $\alpha$-naphthyl acetate showed diffuse bands in the 720 to $1048 \mathrm{kDa}$ native protein marker range for LNCaP, DU145 and PC3 cell lysates that were faintly present in the RWPE-1 or RWPE-2 cell lysates. The staining intensity with $\alpha$-naphthyl acetate in the 720 to $1048 \mathrm{kDa}$ region was greater for the LNCaP, DU145 and PC3 cell lysates compared to the RWPE-1 or RWPE-2 cell lysates.
Parallel gels stained with S-ANAA or R-ANAA show two prominent and sharp esterase bands at $216 \mathrm{kDa}$ and $198 \mathrm{kDa}$ native protein marker points. Densitometry analysis of the $216 \mathrm{kDa}$ band showed significantly higher esterase activity in the LNCaP cell lysate stained with R-ANAA and S-ANAA compared to all other cell lysates (Figure 4B). Moreover, the $216 \mathrm{kDa}$ band for $\mathrm{LNCaP}$ cells showed higher activity with the S-ANAA substrate compared to the R-ANAA substrate. The degree of chiral substrate selectivity was more apparent in the esterase activity of the $198 \mathrm{kDa}$ band (Figure 4C). Densitometry of the $198 \mathrm{kDa}$ band showed a significant preference for S-ANAA substrate in all of the cell lines except DU 145. The LNCaP lysates contained $40-50 \%$ higher esterase activity in both bands with S-ANAA substrate than with the R-isomer and a 40-60\% higher activity compared to RWPE-1 lysate. RWPE-2 and PC3 lysates had similar staining profiles to RWPE-1, while DU 145 showed less activity compared to RWPE-1.

The n-PAGE esterase profiles obtained with S- or RAANA showed fewer and more distinct bands than with the $\alpha$-naphthyl acetate. We, therefore, focused on determining the identity of the protein(s) in the more active $198 \mathrm{kDa}$ band. This band was excised, trypsinized, and the resulting peptides were subjected to mass spectrometry analysis to identify the esterase(s) responsible for the activity. As shown in Table 1, we identified oxidized protein hydrolase $(\mathrm{OPH})$, also called $\mathrm{N}$-acylaminoacylpeptide hydrolase, or acylamino-acid-releasing enzyme (EC 3.4.19.1) in the $198 \mathrm{kDa}$ band. OPH is a serine esterase/ protease with a well characterized exopeptidase activity for removing $\mathrm{N}$-terminally acetylated residues from peptides [15-17]. These LC-MS/MS results as well as the hydrolysis of the ANAA substrates by the $198 \mathrm{kDa}$ band are consistent with the known activity of $\mathrm{OPH}$ to remove $\mathrm{N}$-terminally acetylated alanine residues.

LNCaP lysates showed significantly higher levels of esterase activity with $\alpha$-naphthyl acetate and ANAA substrates compared to non-tumorigenic RWPE-1 and tumorigenic RWPE-2, DU145 and PC3 cell lysates. It appears clear that not all tumorigenic prostate cells contain high levels of $\mathrm{OPH}$ activity; however, the human protein atlas (http://www.proteinatlas.org/) indicates that some human tumors overexpress OPH compared to normal prostate tissue. Since the overexpression of OPH in tumors compared to normal prostate tissue is the most ideal situation for OPH targeted prodrugs, we have limited the remainder of this study to the non-tumorigenic RWPE-1 and tumorigenic LNCaP cell lines.

\section{Esterase activity profiles with n-PAGE electroblotting}

In order to further validate the nanospray-LC-MS/MS results we next tested the possibility that: (1) esterase activity could be maintained after n-PAGE electroblotting; 


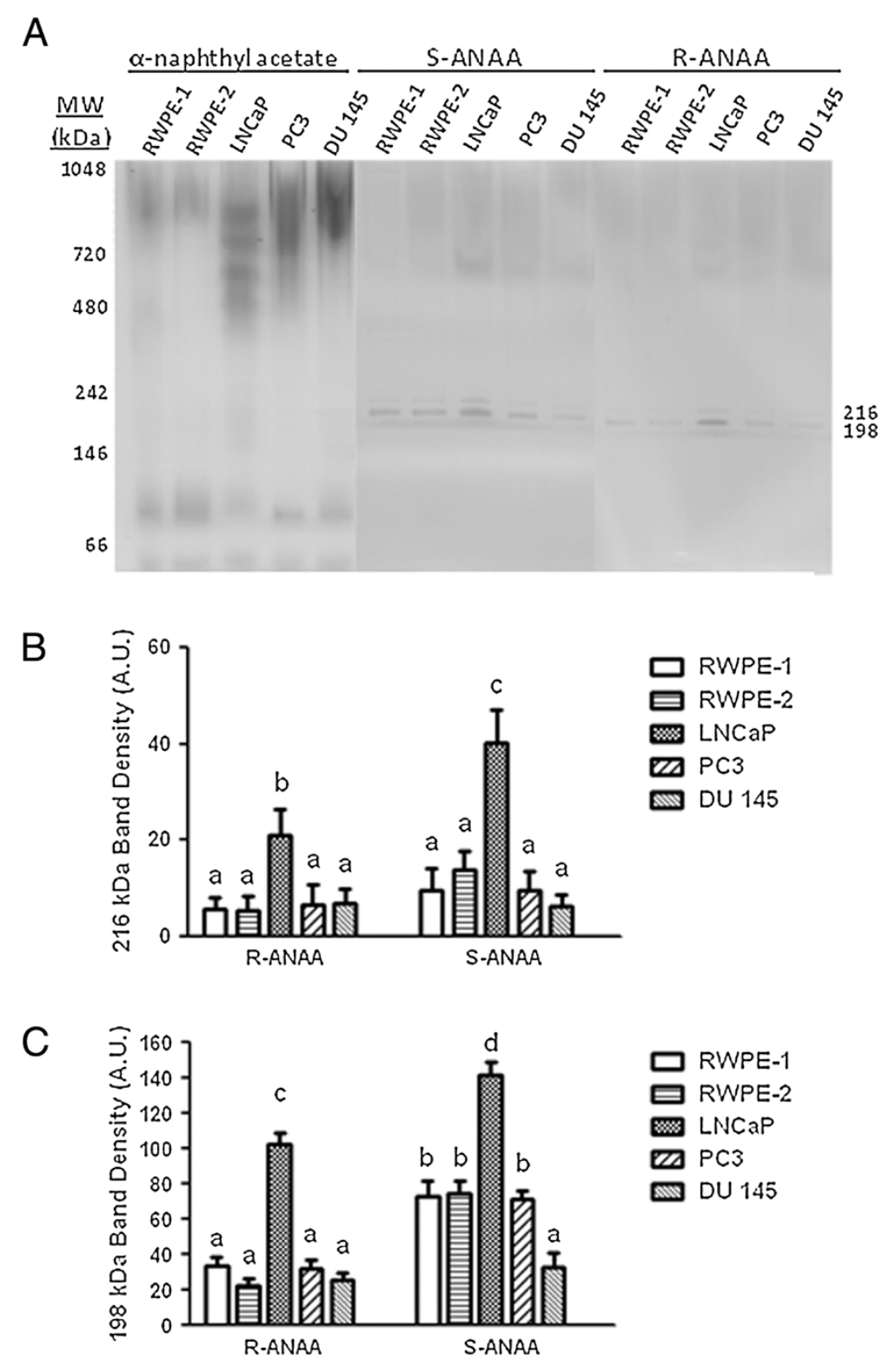

Figure 4 Prostate cell lysate esterases form distinct bands when separated by $6 \%$ n-PAGE. A) RWPE-1, RWPE-2, LNCaP, DU 145, and PC3 cell lysates containing $120 \mu \mathrm{g}$ of protein were separated by $6 \% \mathrm{n}$-PAGE followed by staining with either $800 \mu \mathrm{M}$ a-naphthyl acetate, S-ANAA, or R-ANAA. Native molecular weight markers (left side) were used to calculate the relative migration of some esterase bands (right side). The B) $216 \mathrm{kDa}$ and C) $198 \mathrm{kDa}$ esterase bands visualized with S-ANAA were measured by densitometry. Letters that are not the same are significantly different at $\mathrm{P}<0.05$.

(2) immunostaining could be used to confirm the presence of $\mathrm{OPH}$ protein in the n-PAGE esterase activity bands; (3) nanospray-LC-MS/MS could be performed on the electroblotted esterase bands. RWPE- 1 and LNCaP lysates were separated on 6\% n-PAGE gels and the proteins transferred to a nitrocellulose membrane by electroblotting and the esterase bands visualized by activity staining of the membrane with S-ANAA substrate. As shown in Figure 5A, this methodology resulted in the appearance of two additional sharp bands in the $220-240 \mathrm{kDa}$ native protein marker region of the blot. A parallel blot was probed with anti-OPH antibody to confirm the proteomic identification of $\mathrm{OPH}$ within the activity bands. The esterase activity was quantified using densitometry analysis (Figure 5B) and the LNCaP activity bands showed about a $50 \%$ higher esterase activity compared to the respective RWPE-1 activity bands. Densitometry of the anti-OPH immunoblot (Figure 5C) revealed relative intensity patterns that paralleled that seen for the activity bands. The four OPH activity bands were excised separately and each 
Table 1 LC/MS-MS analysis of 198 kDa n-PAGE bands

\begin{tabular}{lcc}
\hline \multicolumn{1}{c}{ Protein Identical } & P & MW(Da) \\
\hline N-acylaminoacyl-peptide hydrolase (OPH) & $3.116 \mathrm{E}-08$ & 81172.77 \\
\multicolumn{1}{c}{ OPH Peptides Indentified } & $\mathbf{P}$ & $\mathbf{M W ( D a )}$ \\
R.LLLYPK.S & $4.144 \mathrm{E}-01$ & 136.96 \\
K.TPLLLMLGQEDR.R & $3.128 \mathrm{E}-07$ & 440.43 \\
R.SALYYVDLIGGK.C & $1.171 \mathrm{E}-07$ & 1180.98 \\
K.STHALSE VE VE SDSFMNAVLWLR.T & $1.159 \mathrm{E}-01$ & 213.91 \\
KVGFLP SAGK.E & $5.348 \mathrm{E}-01$ & 280.19 \\
K.ALDVSASDDEIAR.L & $2.568 \mathrm{E}-07$ & 1461.57 \\
K.VTSWWDWPR.Q & $1.285 \mathrm{E}-04$ & 966.14 \\
K.SFNLSALEK.H & $2.434 \mathrm{E}-03$ & 512.27 \\
K.QFLEVWEK.N & $2.718 \mathrm{E}-04$ & 201.26 \\
R.GSTGFGQDSILSLPGNVGHQDVK.D & $4.639 \mathrm{E}-02$ & 266.86 \\
K.MGFAVLLVNYR.G & $1.412 \mathrm{E}-01$ & 1143.36 \\
R.SALYYVDLIGGK.C & $5.262 \mathrm{E}-01$ & 567.34 \\
K.GDQFVFYEDWGENMVSK.S & $7.935 \mathrm{E}-02$ & 195.47 \\
R.QDLFAVDTQVGTVTSLTAGGSGGSWK.L & $3.116 \mathrm{E}-08$ & 323.53 \\
K.EQSVLWVSLEEAEPIPDIHWGIR.V & $8.643 \mathrm{E}-02$ & 382.15 \\
\hline A. & &
\end{tabular}

A representative list of OPH peptide identified within the $198 \mathrm{kDa}$ esterase band by mass spectrometry. Peptide coverage was $24.6 \%$ of the full OPH protein sequence. $P$ indicate the probability that the protein or peptide is a random match to the spectral data.

band analyzed by LC/MS-MS. As detailed in Table 2, $\mathrm{OPH}$ was identified within the most active activity bands (bands 2-4) but could not be consistently identified within the least active band (band 1). We also noted that the esterase activity profiles with n-PAGE electroblotting had a lower level of background staining than similarly stained native gels.

\section{$\mathrm{OPH}$ accounts for the all the esterase staining observed with the S-ANAA substrate}

We next investigated whether the apparent esterase activity with the S-ANAA substrate observed in the 198 and $216 \mathrm{kDa}$ bands was due completely to OPH. NativePAGE gels run with LNCaP or RWPE-1 lysates were preincubated with $50 \mu \mathrm{M}$ diisopropyl fluorophosphate (DFP), a known irreversible inhibitor of serine esterases/proteases and of OPH [23], before activity staining with S-ANAA substrate (Figure 6A). The $198 \mathrm{kDa}$ and $216 \mathrm{kDa}$ esterase bands showed no visible activity after pre-incubation with DFP, indicating that the esterase activity observed was completely due to a serine hydrolase activity. We further confirmed this finding by pre-clearing the cell lysates with anti-OPH antibody prior to n-PAGE esterase activity profiling (Figure 6B). Activity staining with S-ANAA revealed that cell lysates pre-cleared with anti-OPH antibody had no detectable esterase activity further confirming that the esterase activity observed with S-ANAA was due specifically and completely to $\mathrm{OPH}$.

\section{$\mathrm{OPH}$ present in prostate cell lysates appears as a single MW weight species in SDS-PAGE Westerns}

Since we observed multiple OPH bands in prostate cell lysates with n-PAGE, we next wanted to determine if SDS-PAGE gels similarly had multiple bands or a single $\mathrm{OPH}$ polypeptide with the known MW $(81 \mathrm{kDa})$ of the $\mathrm{OPH}$ monomer. Western blots of non-tumorigenic RWPE1 and tumorigenic LNCaP, DU 145, and PC3 cell lysates were found to be a single $81 \mathrm{kDa}$ band (Figure 7A). Densitometry analysis showed significant differences in $\mathrm{OPH}$ expression levels among the four cell lines (Figure 7B). LNCaP cell lysates contained approximately $40 \%$ more OPH than RWPE-1, while DU 145 and PC3 lysates contained less OPH (50\% and 25\% respectively) than RWPE-1.

Mammalian OPH has been primarily reported as a homotetramer $[16,24,25]$ with each OPH subunit being active within the tetramer. It has been shown that citraconylation of the amino groups of purified OPH tetramer reversibly dissociates the quaternary structure of $\mathrm{OPH}$. When acylated with citraconic anhydride, OPH separated by n-PAGE forms multiple OPH bands [26]. Interestingly, our prostate cell lysates produced four uniformly distributed activity bands when separated by n-PAGE. Some explanations for the multiple OPH activity bands are $\mathrm{OPH}$ multi-mers, isoforms, degradation products, protein interactions, and post-translational modifications. $\mathrm{OPH}$ isoforms and degradation products appear to be unlikely causes for the multiple bands. Isoforms and degredation products typically result in multiple bands when separated by SDS-PAGE; however, western blots of the prostate lysates reveal a single $80 \mathrm{kD}$ OPH band. The interaction of native $\mathrm{OPH}$ with other proteins is plausible.

There is evidence that under conditions of oxidative stress OPH translocates to the cell membrane of erythrocytes and degrades oxidized proteins [27]. Similarly, $\mathrm{OPH}$ was found to translocate to the aggresome when the proteasome was inhibited in COS-7 cells [28]. High levels of oxidative stress are known to oxidize proteins resulting in protein aggregations that can inhibit the proteasome [29]. LNCaP, DU 145, and PC3 cell lines are reported to have significantly higher free radical production compared to RWPE-1 [30], which might induce $\mathrm{OPH}$ to interact with aggresomal or membrane proteins. Our mass spectrometry analysis of the $\mathrm{OPH}$ bands revealed several proteins known to be associated with aggresomes and were consistent with previously published data [31]. We are actively pursuing an explanation for the multiple OPH bands.

\section{The higher expression of OPH protein in LNCaP cell lysates is reflected by a higher activity towards $\mathrm{N}$-acetyl-alanyl-p-nitroanilide}

$\mathrm{N}$-acetyl-alanyl-p-nitroanilide (AcApNA) (Figure 1D) is a specific $\mathrm{OPH}$ substrate and is routinely used to 


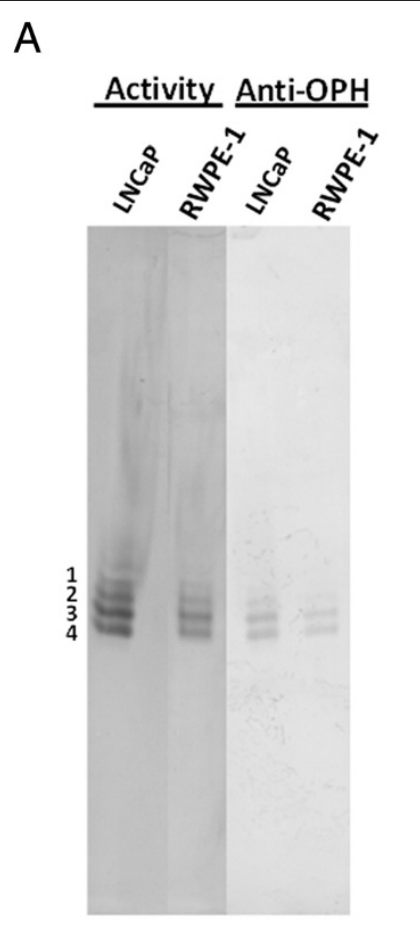

B

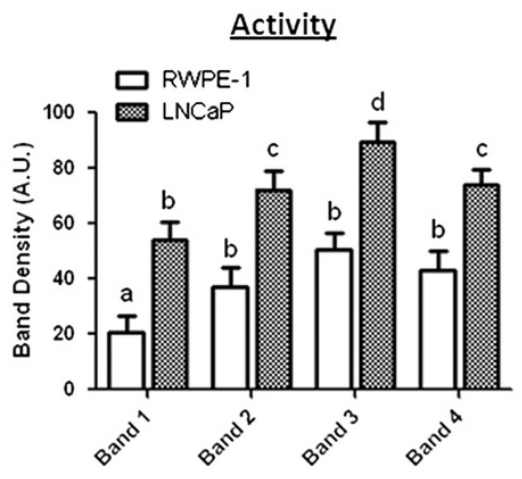

C

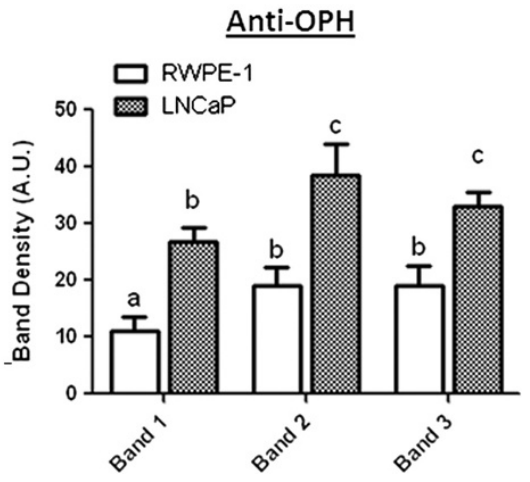

Figure 5 Native electroblot activity staining and anti-OPH reveal OPH bands. LNCaP and RWPE-1 cell lysates each containing $120 \mu \mathrm{g}$ of protein were subjected to $6 \% \mathrm{n}$-PAGE followed by electroblot transfer to a nitrocellulose membrane. A) The blot was stained with 800 MM S-ANAA and Fast Blue RR salt. A parallel unstained blot was probed with anti-OPH as stated in the Materials and methods section. B) The esterase activity and $\mathbf{C}$ ) anti-OPH bands were measured by densitometry and expressed in arbitrary units (A.U.). Letters that are not the same are significantly different at $P<0.05$.

measure $\mathrm{OPH}$ activity and follow $\mathrm{OPH}$ purification from tissue homogenates $[16,24,25,28]$. The product p-nitroaniline (p-NA) is released upon hydrolysis of AcApNA and its absorbance measured at $405 \mathrm{~nm}$. We found that non-tumorigenic and tumorigenic cell lysates incubated with AcApNA released p-NA at differential rates (Figure $7 \mathrm{~B}$ ). After 10 minutes of incubation with AcApNA, LNCaP lysates released approximately $40 \%$ more p-NA than RWPE-1 lysates. PC3 lysates released approximately $15 \%$ more p-NA compared to RWPE-1, while the rates for AcApNA hydrolysis were similar for DU 145 and RWPE-1. The activity profile of the prostate cell lysates incubated with the known $\mathrm{OPH}$ substrate AcApNA parallel the expression of $\mathrm{OPH}$ observed by SDS-PAGE Western blots (Figure 7A) as well as the esterase activity profiles observed for n-PAGE stained with S-ANAA. As expected, porcine liver esterase (PLE) had no activity towards the AcApNA substrate.

\section{The esterase substrates enter prostate cells and have} measurable in situ esterase activities

As indicated in Figure 8, we next compared the esterase activities within LNCaP and RWPE-1 cultured prostate epithelial cells by incubating intact cells with $\alpha$-naphthyl acetate or the chiral ANAA substrates. We found that LNCaP cells had higher in situ esterase activity with all three substrates compared to RWPE-1 (Figure 8A). Analyses of the areas stained (Figure 8B) showed that $\alpha$-naphthyl acetate stained LNCaP cells approximately three-fold more than RWPE-1 cells. RWPE-1 cells showed no significant difference in staining between the chiral ANAA substrates; however, the LNCaP cells had a five-fold higher esterase activity level with S-ANAA compared to R-ANAA. LNCaP cells also had five-fold higher activity with S-ANAA than RWPE- 1 cells. These data clearly demonstrate that the ester substrates are permeable to the plasma membrane, which is typical of neutral esters.

Human OHP overexpressed in COS-7 has characteristics similar to that of OPH in the human prostate epithelial cell lines

As a positive control, we next repeated the in situ experiment with COS-7 cells and COS-7-OPH cells which overexpress OPH (Figure 9A). As expected, based on our n-PAGE experiments (Figure 4A), there was no increase in COS-7-OPH with in situ staining when $\alpha$-naphthyl acetate was used since it was not found to be a substrate for $\mathrm{OPH}$. 
Table 2 Electroblot esterase activity bands contain OPH B and 2

Protein Identified
N-acylaminoa cly-peptide hydrolase
Peptides Identified
R.QVLLSEPEEAAALYR.G
K.ALDVSASDDEIAR.L
K.SFNLSALEK.H
K.AESFFQTK.A
R.WFDSAQR.S
R.QVLLSEPEEAAALYR.G

$B$ and 3

Protein Identified

$\mathrm{N}$-acylaminoacyl-peptide hydrolase

Peptides Identified

R.QVLLSEPEEAAALYR.G

R.GSTGFGQDSILSLPGNVGHQDVK.D

K.TPLLLML GQEDR.R

R.NVPVR.D

$B$ and 4

Protein Identified

$\mathrm{N}$-acylaminoacyl-peptide hydrolase

Peptides Identified

K.SPIR.Y

K.SFNLSALEK.H

R.QVLLSEPEEAAALYR.G

LC/MS-MS of the bands excised from an activity stained native electroblot membrane confirmed the presence of $\mathrm{OPH}$. $\mathrm{OPH}$ was not consistently identified in band $1 . \mathrm{P}$ indicates the probability that the protein or peptide is a random match to the spectral data.

However, there were significant increases in esterase activity staining with the chiral ANAA substrates. There was approximately a seven-fold increase in esterase activity staining with S-ANAA in the COS-7-OPH cells compared to the non-transfected COS-7 cells. Moreover, there was approximately $50 \%$ more esterase activity staining with the S-isomer compared to the R-isomer. As indicated in Figure 9C, SDS-PAGE Western blots of COS-7 and COS-7-OPH lysates using anti-OPH antibody confirms the marked overexpression of $\mathrm{OPH}$ in the $\mathrm{COS}-7-\mathrm{OPH}$ cells. Additionally, n-PAGE activity profiling with S-ANAA and the $\mathrm{OPH}$ activity assay confirms the overexpression of active $\mathrm{OPH}$ in the COS-7-OPH cells and also show the $\mathrm{OPH}$ activity is present in two main bands (Figure 9D). Lysates of COS-7 and COS-7-OPH were incubated with AcApNA for $10 \mathrm{~min}$ and the p-NA released was compared (Figure 9E). COS-7-OPH lysates showed approximately a seven-fold higher p-NA release compared to COS-7 lysates.

\section{Discussion and Conclusion}

A number of investigators have suggested that chiral ester prodrugs hold the promise of providing more selective anticancer chemotherapy [7-9,11,14]. A major requirement for this strategy is the need to identify target esterases that have differential expression or substrate selectivity in cancer cells compared to their normal counterpart. Ideally, esterases targeted for prodrug hydrolysis should be highly expressed in the target tumor cells and/or have a chiral preference different from normal cells. Yamazaki et al. previously found that several cancers displayed hydrolytic preferences for isomers of chiral substrates opposite that of their normal counterparts $[13,14,32]$. However, in the work presented here we found that the esterases of both tumorigenic and non-tumorigenic prostate cells both showed a preference for the $\mathrm{S}$-isomer of $\alpha$-naphthyl $\mathrm{N}$-acetyl-alaninate (S-ANAA).

Additionally, we have improved upon the work by Yamazaki et al. by identifying a specific esterase that has differential activity towards chiral ANAA substrates. We have used several proteomic techniques to identify $\mathrm{OPH}$ in tumorigenic and non-tumorigenic prostate cells. Using an n-PAGE method similar to Yamazaki et al., n-PAGE electroblotting, immunoblotting, inhibition studies and mass spectrometry we have identified $\mathrm{OPH}$ in prostate cells and have found that $\mathrm{OPH}$ has selective activity towards chiral ANAA substrates.
A

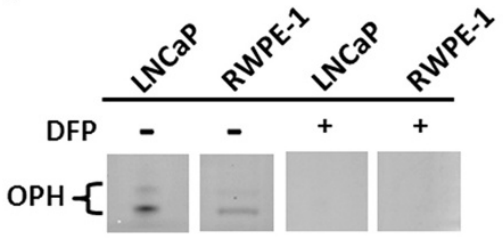

B

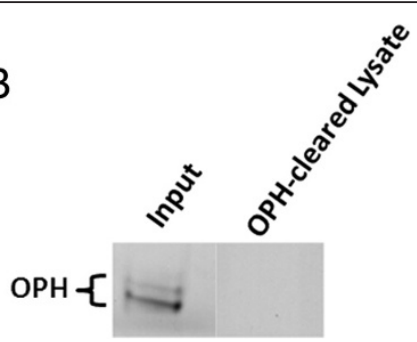

Figure 6 Pre-clearance of OPH or inhibition by DFP ablates OPH activity bands. A) LNCaP and RWPE-1 lysates were separated by $6 \%$ n-PAGE. The gel was pre-incubated in phosphate buffer or phosphate buffer containing $50 \mu \mathrm{M}$ DFP for 30 min. Esterase activity bands were visualized with S-ANAA and Fast Blue RR salt. B) LNCaP lysates containing $120 \mu \mathrm{g}$ of protein were pre-cleared with protein A beads or anti-OPH antibody bound to protein A beads. The collected lysates were separated by 6\% n-PAGE and the esterase activity visualized with S-ANAA and Fast Blue RR salt. 


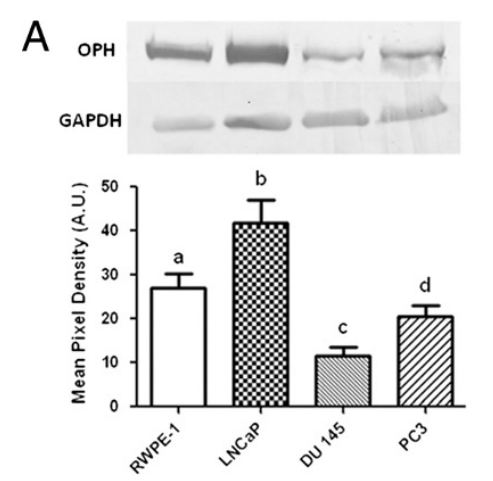

\section{B}

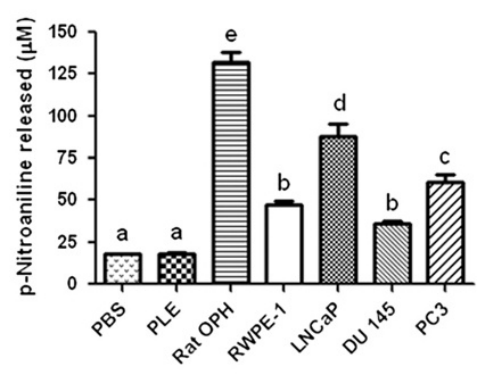

Figure 7 OPH protein levels are differentially expressed in prostate cell lysates. A) RWPE-1, LNCaP, DU 145, and PC3 lysates containing $90 \mathrm{\mu g}$ of protein were separated by 6\% SDS-PAGE, transferred to a nitrocellulose membrane, and probed with anti-OPH antibody. Anti-OPH bands were measured by densitometry and expressed in arbitrary units (A.U.). B) RWPE-1, LNCaP, DU 145, and PC3 lysates containing $90 \mu \mathrm{g}$ of protein were incubated with $4 \mathrm{mM}$ AcApNA and the amount of p-nitroaniline released after 10 minutes were calculated. PLE (0.5 units) and semi-purified rat liver $\mathrm{OPH}(250 \mathrm{ng})$ were used as negative and positive controls respectively. Letters that are not the same are significantly different at $\mathrm{P}<0.05$.

$\mathrm{OPH}$ is a serine protease and a member of the prolyl oligopeptidase (POP) family. Three functions of OPH have been described: (1) an exopeptidase activity that unblocks $\mathrm{N}$-acetyl peptides with a preference for $\mathrm{N}$-acetyl alanyl peptides [16]; (2) an endopeptidase activity towards oxidized and glycated proteins [28,33-36] and; (3) an ability to associate with aggresomes when proteasome function is inhibited [28]. Moreover, work by Shimizu et al. [28] suggests that the proteasome and $\mathrm{OPH}$ work coordinately to clear cells of oxidized (carbonylated) proteins. A comprehensive

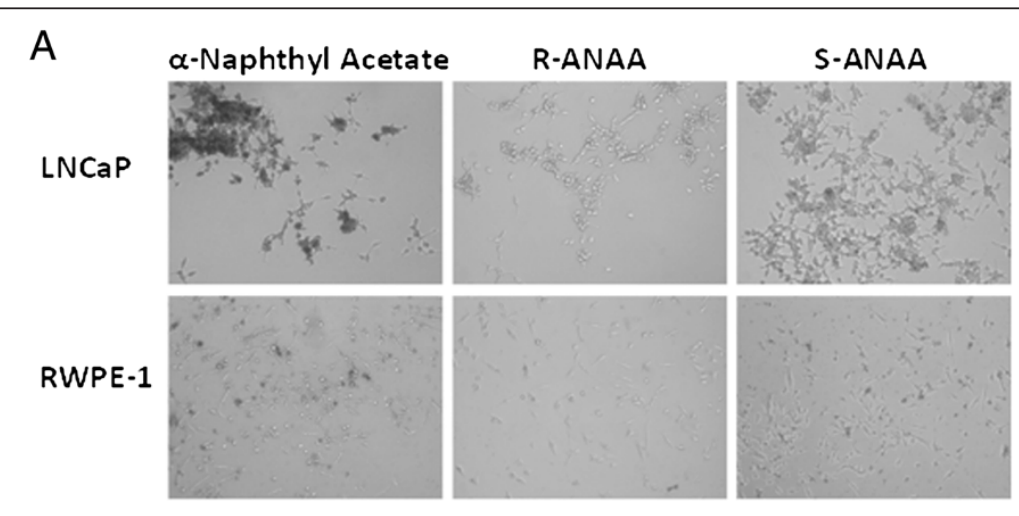

B

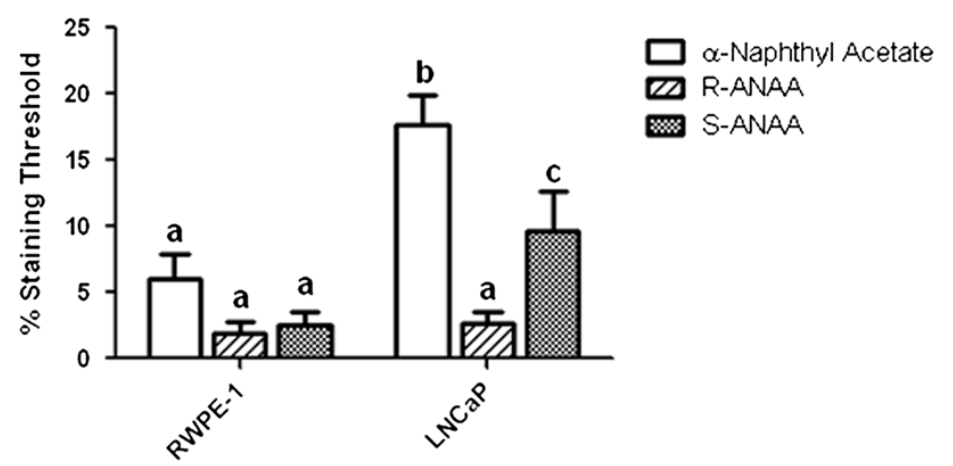

Figure 8 LNCaP prostate cancer cells contain higher esterase activity than non-tumorigenic RWPE-1 cells. A) LNCaP and RWPE-1 cell cultures were incubated with $800 \mu \mathrm{M}$ a-naphthyl acetate, R-ANAA, or S-ANAA substrate and Fast Blue RR salt for 20 min. The dark color indicates in situ esterase activity. B) Microscopy images were analyzed with ImageJ to measure the relative staining between cell lines. Percent area threshold was defined as the percent area stained that exceeded background staining. Letters that are not the same are significantly different at $\mathrm{P}<0.05$. 

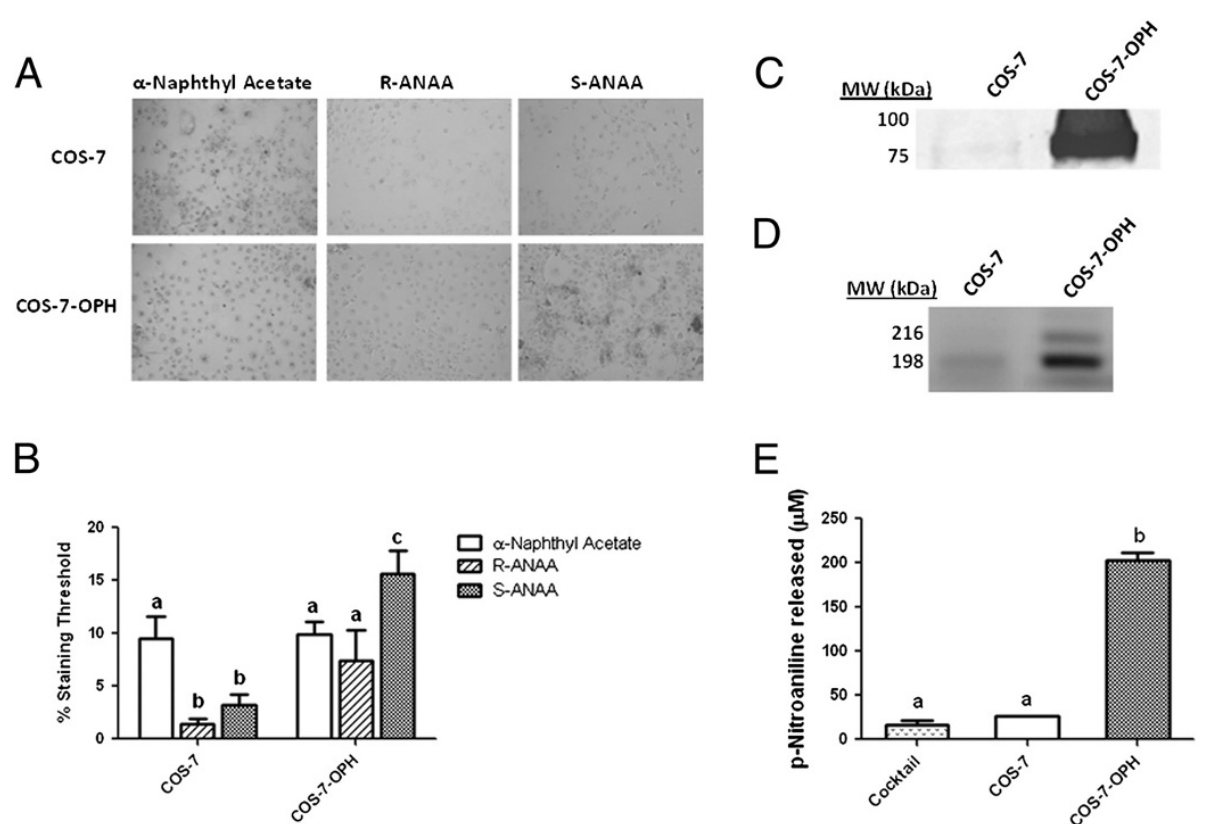

Figure 9 COS-7 cells that over-express OPH show higher levels of ANAA hydrolysis. A) COS-7 and COS-7-OPH cells were treated with 800 MM a-naphthyl acetate, R-ANAA, or S-ANAA substrate and Fast Blue RR salt for 20 minutes. Dark color indicates esterase activity. B) Microscopy images were analyzed with ImageJ to measure the relative staining between cell lines. Percent area threshold was defined as the percent area stained that exceeded background staining. C) Anti-OPH Western blot of COS-7 and COS-7-OPH lystates containing $90 \mu \mathrm{mg}$ of total protein. D) Cell lysates containing $120 \mu \mathrm{g}$ of protein were separated by $6 \%$ n-PAGE followed by staining with $800 \mu \mathrm{M}$ S-ANAA. E) Lysates were incubated with $4 \mathrm{mM} \mathrm{N}$-acetyl-L-alanyl-p-nitroanilide and the amounts of p-nitroanaline released after 10 minutes were measured. Letters that are not the same are significantly different at $\mathrm{P}<0.05$.

physiological understanding of OPH remains elusive. Nevertheless, the acetylation of the N-terminal $\alpha$-amine group of proteins is the most common post-translational modification in eukaryotic proteins yet, little is known about the biological role of $\mathrm{N}$-alpha-terminal acetylation, and even less is known about the role of enzymes (like $\mathrm{OPH}$ ) that catalyze the hydrolysis of an $\mathrm{N}$-terminally acetylated peptide to release an $\mathrm{N}$-acetylamino acid.

Our finding that $\mathrm{OPH}$ in non-tumorigenic and tumorigenic prostate cell lines have a greater hydrolytic preference for the S-ANAA isomer of ANAA is consistent with previous observations that $\mathrm{OPH}$ has a preference for small peptides with Ac-L-alanine (Ac-S-alanine) compared to Ac-D-alanine (Ac-R-alanine) [37]. OPH activity bands were not observed with the $\alpha$-naphthyl acetate substrate while distinct activity bands were visualized using $\alpha$-naphthyl $\mathrm{N}$-acetyl-alaninate substrates. In addition, OPH has high specificity for AcApNA and Ac-Ala- $\beta$ naphthylamide [16]. AcApNA and Ac-Ala- $\beta$-naphthylamide are structurally similar to ANAA; the main differences being the 4-nitrobenzene of AcApNA and the peptide bond of Ac-Ala- $\beta$-naphthylamide. AcApNA, Ac-Ala- $\beta-$ naphthylamide, and ANAA contain N-terminal acetylated alanine. Taken together, this family of small $\mathrm{N}$-acetylalaninate substrates appears to be good models for future $\mathrm{OPH}$ targeted prodrug designs.
We found $\mathrm{OPH}$ to be differentially expressed in the LNCaP prostate cancer cell line compared to nontumorigenic RWPE-1 cell lines and that tumor cells overexpressing OPH might be responsive to prodrug derivatives of $\alpha$-naphthyl $\mathrm{N}$-acetyl-alaninate. We have found that $\mathrm{OPH}$ expression in prostate cancer cells can vary widely. DU-145 and PC3 lysates showed slightly diminished levels of OPH compared to RWPE-1 while LNCaP contained nearly twofold more OPH than RWPE1. $\mathrm{OPH}$ protein expression levels appear to vary in other cancers as well. Serine protease activity profiling performed by Jessani et al. shows that OPH is highly active in several melanoma and breast cancer cell lines [38]; however, Scaloni previously reported that $\mathrm{OPH}$ was deleted or under-expressed in a number of small cell lung carcinomas [37]. We have screened other tumorigenic cell lines for $\mathrm{OPH}$ activity and have found that several aggressive colon cancer and melanoma cell lines exhibit significantly higher $\mathrm{OPH}$ activity compared to their non-tumorigenic counterparts. Further OPH expression profiling of normal prostate cell lines, prostate cancer cell lines, and primary prostate tissues is needed to determine which prostate cancers might be suitable for OPH-targeted therapies.

$\mathrm{OPH}$ has recently been proposed as a potential target for the development of anticancer drugs [39]. Histological data in the Human Protein Atlas shows that OPH can be 
strongly expressed in some cases of colorectal, breast, prostate, ovarian, endometrial and liver cancers [40]. $\mathrm{OPH}$ has a well-documented substrate specificity towards $\mathrm{N}$-acetylated-L-alaninate esters [41]. Our results suggest that $\alpha$-naphthyl $\mathrm{N}$-acetyl-alaninate substrates could be used to rapidly determine levels of active $\mathrm{OPH}$ in non-tumorigenic and tumorigenic cells and tissues. Naphthyl substrates are routinely used to differentiate chronic myelogenous leukemia (CML) from leukemoid reaction and to distinguish other myeloproliferative disorders $[42,43]$. Yamazaki et al. demonstrated that a substrate similar to S-ANAA, N-methoxycarbonylalaninate, could be used to visualize esterase activity in cryostat tissue sections [32]. Our cell culture activity staining of RWPE-1, LNCaP, and COS-7-OPH cells with S-ANAA suggest that S-ANAA may be useful to screen cells and tissues for relative OPH activity. Screening normal and tumorigenic cells or tissues with S-ANAA may aid in identifying candidates for OPH directed therapies.

In conclusion, we have found that cell lysates from non-tumorigenic RWPE-1 cells and several tumorigenic prostate cell lines display differential esterase activity profiles when visualized with $\alpha$-naphthyl acetate or chiral $\alpha$-naphthyl $\mathrm{N}$-acetyl-alaninate substrates. Our n-PAGE results show that tumorigenic LNCaP, DU 145, and PC3 cell lysates contain higher general esterase activity when visualized with $\alpha$-naphthyl acetate compared to nontumorigenic RWPE-1 cell lysates. In addition, we found that the OPH activity of prostate cell lysates could be visualized by staining with chiral $\alpha$-naphthyl $\mathrm{N}$-acetyl-alaninate substrates, and that OPH has a hydrolytic preference for the S-isomer of ANAA. LNCaP lysates in particular showed the highest esterase activity with all of the ester substrates tested and contained the highest OPH activity measured with AcApNA. The results of this study indicate that ester prodrugs designed after S-ANAA or AcApNA may be a promising therapeutic approach to prostate cancers that overexpress $\mathrm{OPH}$.

\section{Competing interests}

The authors declare that they have no competing interests.

\section{Authors' contributions}

$C M, Y J, V P, M B, K K$, and WS conceived and designed studies, CM, YJ, VP, and $\mathrm{MB}$ acquired and analyzed data, and CM and WS wrote the manuscript. All authors read, edited, and approved the final manuscript.

\section{Acknowledgements}

We thank Dr. Makio Hayakawa for generously providing the pCDNA3.1(+) vector encoding OPH-Flag. This work was supported by East Tennessee State University's School of Graduate Studies Research Grant.

\section{Author details}

${ }^{1}$ Department of Pediatrics, East Tennessee State University, P.O. Box 70579, Johnson City, TN 37614, USA. ${ }^{2}$ Department of Chemistry, East Tennessee State University, Johnson City, TN, USA. ${ }^{3}$ Division of Hematology-Oncology, Department of Internal Medicine, East Tennessee State University, Johnson City, TN, USA.
Received: 19 September 2013 Accepted: 5 February 2014

Published: 10 February 2014

\section{References}

1. American Cancer Society: Cancer Facts \& Figures 2013. Atlanta: American Cancer Society; 2013.

2. Bodey GP, Rodriguez V, McCredie KB, Freireich EJ: Neutropenia and infection following cancer chemotherapy. Int I Radiat Oncol Biol Phys 1976, 1(3-4):301-304.

3. Deinard AS, Fortuny IE, Theologides A, Anderson GL, Boen J, Kennedy BJ: Studies on the neutropenia of cancer chemotherapy. Cancer 1974, 33(5):1210-1218.

4. Dearnaley DP, Khoo VS, Norman AR, Meyer L, Nahum A, Tait D, Yarnold J, Horwich A: Comparison of radiation side-effects of conformal and conventional radiotherapy in prostate cancer: a randomised trial. Lancet 1999, 353(9149):267-272.

5. Randall J, Ream E: Hair loss with chemotherapy: at a loss over its management? Eur J Canc Care (Engl) 2005, 14(3):223-231.

6. Richardson A, Ream E, Wilson-Barnett J: Fatigue in patients receiving chemotherapy: patterns of change. Cancer Nurs 1998, 21(1):17-30.

7. Connors TA, Whisson ME: Cure of mice bearing advanced plasma cell tumours with aniline mustard: the relationship between glucuronidase activity and tumour sensitivity. Nature 1966, 210(5038):866-867.

8. Carl PL, Chakravarty PK, Katzenellenbogen JA, Weber MJ: Protease-activated "prodrugs" for cancer chemotherapy. Proc Natl Acad Sci U S A 1980, 77(4):2224-2228.

9. Watanabe KA, Matsuda A, Halat MJ, Hollenberg DH, Nisselbaum JS, Fox JJ: Nucleosides. 114. 5'-O-Glucuronides of 5-fluorouridine and 5-fluorocytidine. Masked precursors of anticancer nucleosides. J Med Chem 1981, 24(7):893-897.

10. Kageyama $Y$, Yamazaki $Y$, Okuno H: Novel approaches to prodrugs of anticancer diaminodichloroplatinum(II) complexes activated by stereoselective enzymatic ester hydrolysis. J Inorg Biochem 1998, 70(1):25-32.

11. Bardos TJ, Chmielewicz ZF, Hebborn P: Structure-activity relationships of alkylating agents in cancer chemotherapy. Ann N Y Acad Sci 1969, 163(2):1006-1025.

12. Yamazaki Y, Furukawa F, Nishikawa A, Takahashi M, Oka S: Histochemical determination of stereoselectivity of esterases in normal pancreas and pancreatic tubular adenocarcinoma of hamsters. Biotech Histochem 1998, 73(1):23-31.

13. Yamazaki Y, Kageyama Y, Okuno H: Direct evaluation of stereoselectivity of cancer esterases by polyacrylamide gel electrophoresis coupled with activity staining with chiral naphthyl esters. Anal Biochem 1995, 231(2):295-300.

14. Yamazaki Y, Ogawa Y, Afify AS, Kageyama Y, Okada T, Okuno H, Yoshii Y, Nose T: Difference between cancer cells and the corresponding normal tissue in view of stereoselective hydrolysis of synthetic esters. Biochim Biophys Acta 1995, 1243(3):300-308.

15. Jones WM, Scaloni A, Bossa F, Popowicz AM, Schneewind O, Manning JM: Genetic relationship between acylpeptide hydrolase and acylase, two hydrolytic enzymes with similar binding but different catalytic specificities. Proc Natl Acad Sci U S A 1991, 88(6):2194-2198.

16. Kobayashi K, Smith JA: Acyl-peptide hydrolase from rat liver. Characterization of enzyme reaction. J Biol Chem 1987, 262(24):11435-11445.

17. Perrier J, Durand A, Giardina T, Puigserver A: Catabolism of intracellular $\mathrm{N}$-terminal acetylated proteins: involvement of acylpeptide hydrolase and acylase. Biochimie 2005, 87(8):673-685.

18. Koltun D, Parkhill E, Boze M, Zablocki J, Vasilevich N, Mayboroda E, Glushkov A, Cole AG, Chisholm J: Preparation of 3-hydroquinazolin-4-one derivatives and analogs thereof for use as stearoyl CoA desaturase inhibitors. U.S. Pat. Appl. Publ. (2009), US 20090105283 A1 20090423. Chem Abstract 2008(149):471495.

19. Broemme D, Bescherer K, Kirschke H, Fittkau S: Enzyme-substrate interactions in the hydrolysis of peptides by cathepsins $\mathrm{B}$ and $\mathrm{H}$ from rat liver. Biochem J 1987, 245(2):381-385.

20. Tsunasawa S, Narita K, Ogata K: Purification and properties of acylamino acid-releasing enzyme from rat liver. J Biochem 1975, 77(1):89-102.

21. Muller J, Keller HU, Durig P, Hagmann J, Cornioley DM, Reinhard J, Ruchti C, Hess MW, Cottier H: Nonspecific esterase in human lymphocytes. Int Arch Allergy Appl Immunol 1981, 64(4):410-421.

22. Knowles DM, Hoffman T, Ferrarini M, Kunkel HG: The demonstration of acid alpha-naphthyl acetate esterase activity in human lymphocytes: usefulness as a T-cell marker. Cell Immunol 1978, 35(1):112-123. 
23. Miyagi M, Sakiyama F, Kato I, Tsunasawa S: Complete covalent structure of porcine liver acylamino acid-releasing enzyme and identification of its active site serine residue. J Biochem 1995, 118(4):771-779.

24. Sharma KK, Ortwerth BJ: Bovine lens acylpeptide hydrolase. Purification and characterization of a tetrameric enzyme resistant to urea denaturation and proteolytic inactivation. Eur J Biochem 1993, 216(2):631-637.

25. Scaloni A, Barra D, Jones WM, Manning JM: Human acylpeptide hydrolase. Studies on its thiol groups and mechanism of action. J Biol Chem 1994, 269(21):15076-15084.

26. Durand A, Villard C, Giardina T, Perrier J, Juge N, Puigserver A: Structural properties of porcine intestine acylpeptide hydrolase. J Protein Chem 2003, 22(2):183-191.

27. Fujino T, Ando K, Beppu M, Kikugawa K: Enzymatic removal of oxidized protein aggregates from erythrocyte membranes. J Biochem 2000, 127(6):1081-1086

28. Shimizu K, Kiuchi Y, Ando K, Hayakawa M, Kikugawa K: Coordination of oxidized protein hydrolase and the proteasome in the clearance of cytotoxic denatured proteins. Biochem Biophys Res Commun 2004, 324(1):140-146.

29. Davies KJ: Degradation of oxidized proteins by the $20 \mathrm{~S}$ proteasome. Biochimie 2001, 83(3-4):301-310.

30. Kumar B, Koul S, Khandrika L, Meacham RB, Koul HK: Oxidative stress is inherent in prostate cancer cells and is required for aggressive phenotype. Cancer Res 2008, 68(6):1777-1785.

31. Pallotta V, D'Alessandro A, Rinalducci S, Zolla L: Native protein complexes in the cytoplasm of red blood cells. J Proteome Res 2013, 12(7):3529-3546.

32. Yamazaki Y, Oka S: In situ evaluation of esterase stereoselectivity in two-dimensional electropherograms and tissue sections. J Chromatogr B Biomed Sci Appl 1998, 709(2):306-309.

33. Harmat V, Domokos K, Menyhard DK, Pallo A, Szeltner Z, Szamosi I, Beke-Somfai T, Naray-Szabo G, Polgar L: Structure and catalysis of acylaminoacyl peptidase: closed and open subunits of a dimer oligopeptidase. J Biol Chem 2011, 286(3):1987-1998.

34. Nakai A, Yamauchi Y, Sumi S, Tanaka K: Role of acylamino acid-releasing enzyme/oxidized protein hydrolase in sustaining homeostasis of the cytoplasmic antioxidative system. Planta 2012, 236(2):427-436.

35. Shimizu K, Ikegami-Kawai M, Takahashi T: Increased oxidized protein hydrolase activity in serum and urine of diabetic rat models. Biol Pharm Bull 2009, 32(9):1632-1635.

36. Kikugawa K: Defense of living body against oxidative damage. Yakugaku Zasshi 2004, 124(10):653-666.

37. Scaloni A, Jones W, Pospischil M, Sassa S, Schneewind O, Popowicz AM, Bossa F, Graziano SL, Manning JM: Deficiency of acylpeptide hydrolase in small-cell lung carcinoma cell lines. J Lab Clin Med 1992, 120(4):546-552.

38. Jessani N, Liu Y, Humphrey M, Cravatt BF: Enzyme activity profiles of the secreted and membrane proteome that depict cancer cell invasiveness. Proc Natl Acad Sci U S A 2002, 99(16):10335-10340.

39. Palmieri G, Bergamo P, Luini A, Ruvo M, Gogliettino M, Langella E, Saviano M, Hegde RN, Sandomenico A, Rossi M: Acylpeptide hydrolase inhibition as targeted strategy to induce proteasomal down-regulation. PLOS One 2011, 6(10):e25888

40. Uhlen $M$, Oksvold P, Fagerberg L, Lundberg E, Jonasson $K$, Forsberg $M$, Zwahlen M, Kampf C, Wester K, Hober S, Wernerus H, Bjorling L, Ponten F: Towards a knowledge-based human protein atlas. Nat Biotechnol 2010, 28(12):1248-1250.

41. Gade W, Brown JL: Purification and partial characterization of alpha-N-acylpeptide hydrolase from bovine liver. J Biol Chem 1978, 253(14):5012-5018.

42. KAPLOW LS: A histochemical procedure for localizing and evaluating leukocyte alkaline phosphatase activity in smears of blood and marrow. Blood 1955, 10(10):1023-1029.

43. Lippi U, Cappelletti P, Schinella M: Alpha-naphthyl butyrate esterase (a selective cytochemical monocyte marker). Ric Clin Lab 1983, 13(4):467-471.

doi:10.1186/1471-2407-14-77

Cite this article as: McGoldrick et al: Identification of oxidized protein hydrolase as a potential prodrug target in prostate cancer. BMC Cancer 2014 14:77.

\section{Submit your next manuscript to BioMed Central and take full advantage of:}

- Convenient online submission

- Thorough peer review

- No space constraints or color figure charges

- Immediate publication on acceptance

- Inclusion in PubMed, CAS, Scopus and Google Scholar

- Research which is freely available for redistribution 